\section{AZ EURÓPAI TÁJ EGYEZMÉNY \\ MEGVALÓSÍTÁSA MAGYARORSZÁGON \\ - RÖVID ÁTTEKINTÉS}

IMPLEMENTATION OF THE EUROPEAN

LANDSCAPE CONVENTION IN HUNGARY - SHORT REVIEW

\section{SZERZÖ / BY:}

HTPS://DOI.ORG/
$10.36249 / 53.4$

Az Európa Tanács Európai Táj Egyezményét az Európa Tanács Miniszteri Bizottsága 2000. július 19-én fogadta el, é 2000. október 2o-án Firenzében nyitott meg aláírására a tagállamok részére. Magyarország azonnal megkezdte a vég-
rehajtás elókészitését. Az Európa Tanács Európai Táj Egyezménye 2008. február 1-jén lépett hatályba Magyarországon. 2008 és 2010 között Magyarország elsősorban az végrehajtás intézményi keretének megteremtésén és a Tájdij életre hívásán dolgozott. Magyarország 2008 óta hirdet pályázatot az Európa Tanács Táj Díjára történő felterjesztés nemzeti jelöltjének kiválasztására. 2012-ben a természetvédelemért felelös miniszter a Magyar Tá dij létrehozáśńval rer a Magyar Tajkiválasztási eljárást. Jelentőss siker-

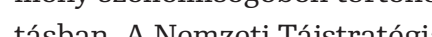

The Europenn Landscape Convention of the Council of Europe was a adopted by the Committee of Ministers of the Councll of Europe on 19 July 2000 and opened for signature to its Member States in Florence on 20 October 2000. Hungary immediately began the process of preparing for its implementation. The European Landscape Convention finally came into force on 1 February 2008 in Hungary. Between 2008 and 2010 Hungary worked mainly on the institutional framework of the implementation and the establishment of the Landscan Award. Since 2008 Hungary opcape Award. Since 2008 Hungary opened a comperition for selecting the national coun the Council of Eupe. In 2012 the Minister responile for na tion raised the status of the selection procedure establishing the Hungarian Landscape Award. This achieved some remarkable success because in 2015 based on the submission from Hungary the Landscape Award of the Council of Europe was given to the Hungarian an Slovenian villages of the Hetés Region. After consolidating the institutional framework, the European Landscape Convention National Coordination Working Group expanded its focus to all the general and special measures of the Convention. Hungarian Government approved Hungary's first Nationa Landscape Strategy for the period 2017 2026 which focused attention on the need for a holistic landscape approach Since the approval of the National Lan since the approval of the National La an important reference document.
Szent Istún University Faculty of Szlon ning plays a key determining role in ndscape education in the spirit of the uropean Land convention. The (anean Landscape Convention. The my emparional Landscape Statemphasises that passing on landscape-related knowledge needs not be included in engineering courses and any other courses whose graduates will influence the condition and use of landcapes through their future decisions. Action is still required to achieve the pring for is the in is (the basic In Octe n pew project 'Strategic assessments supporting the long-term conservation of natural values of community interest as well as the national implementation of the EU Biodiversity Strategy to 2020" (KEHOP-4.3.-V-VEKOP-15-2016-00001) garian Operational Programme 'Environment and Energy', co-funded by the European Regional Development Fund. In the preparation phase of the LANDSCAPE CHARACTER development element, experience of foreign and domestic landscape typological and landscape identification systems and their practical applicability, with focus on character-based systems, were studied. According to the results from the preparatory phase the outputs can have positive phase, the outputs can have positive to people concerned prime objective which, in higher the this was introduced under the Hun-

The products of the project will be delivered to the Ministry of Agriculture which will consider how these results can be integrated into policies and de sion-making mechanisms after professional preparation and administrative consultations. This will contribute significantly to the achievement of some of the objectives of the landscape strategy. The Minister of Agriculture is obliged to produce a three-yearly report on the implementation of the landscape strategy to the Government. The next report is due on the 30 June 2020. This article presents an outline of the important national and internetional milestones the Hungarion ernent has mode in the implan Govtion of the Eurowe in the vention of the Council of Europe.

\section{ACKNOWLEDGEMENT}

I must express a very warm thanks to Mrs Maguelonne Déjeant-Pon Executive Secretary of the European Landscape Convention, whose identification with the subject, conscientious and helpful work succeeded the Convention in Europe. 39 ratifications and two more signatures from the 47 Member States are proof of her excellent work. Maguelonne Déjeant-Pons is working hard on that states who has not ratified the Convention became parties to it, and to promote the implementation in all states without derogating from the provisions of the Convention. from the provisions of the senyképes Közép-Magyarom és a Ve ratív Program keretében, 2016-ban átfogó projektet „A közösségi jelen- 
tőségủ természeti értékek hosszú távú megörzését és fejlesztését, valamint az EU Biológiai Sokféleség Stratégia 2020 célkitűzéseinek hazai szintủ megvalósítását megalapozó stratégiai vizsgálatok" (KEHOP-4.3.o-VEOP-15-2016-00001) indított útjára. A TAJKARAKTER fejlesztési elem elökészittese során kerultek feldolgozásra a kulfoldi és hazai tájtipizálási és tájbeosztási rendszerek tapasztalatai és gy korlati alkalmazhatóságuk, különös tekintettel a tájkarakter alapú rendsz rekre. Az előkészítỏ szakasz feltárása szerint a kutatás eredményei kedvező hatást fejtenek ki a közigazgatásban. A projekt eredmennytermékei az Agraminisztériumhoz kerülnek, melyek szakmai előkészítések és közigazgatási egyeztetések után épülhetnek be a szakpolitikákba, döntési mechanizmusokba. Ez jelentős mértékben járul majd hozzá a Tájegyezményből származó kötelezettségek teljesitéséhez és a Tájstratégia egyes céljainak megvalóśtáśáhez A mezögazdaśgi minisztor nek háromévente be kell nia a kormánynak a Tájstratégia végrehajtásáról. A következő jelen-

A cikk az Európa Tańcs Eunópai Taj A Éśén tós

\section{KÖSZÖNETNYILVÁNíTÁS}

Köszönetemet szeretném kifejezni Maguelonne Déjeant-Pons asszonynak, az Európai Táj Egyezmény fótitkárának, akinek a témával való azonosulása, lelkiismeretes és segitōkész munkája nélkül nem lehetne az Európai Táj Egyezmény sikeres. 39 ratifikálás és további két állam aláirása a 47 tagállamból az ô munkáját igazolja. Maguelonne Déjeant-Pons asszony töretlen lendülettel dolgozik azon, hogy a még nem csatlakozott államok is csatakozzanak, és a végrehajtás minden országban csorbítatlan módon, az egyezmény rendelkezéseitól való eltérés nétkül történjen.
1. ábra/fig.: A táj
életünk tere és alakitioj, gondolataink ihletójje, érréseink formálója. A
TÁKARAKTER fejlestési TAKARAKTER Fejlesztési elem roll-up-ja. / The
landscape is the space and drivers of our life, the inspiration of our thoughts, a source forming our feelings. The
roll-up of the LANSCAPE roll-up of the LANDSCAPE
CHARACTER development element
(FoRRÁS/SOURCE: ACRÁRMINISZTÉRIUM tájkarakter a természet arcai

A táj életünk tere és alakitója, gondolataink ihletője, érzéseink formálója.

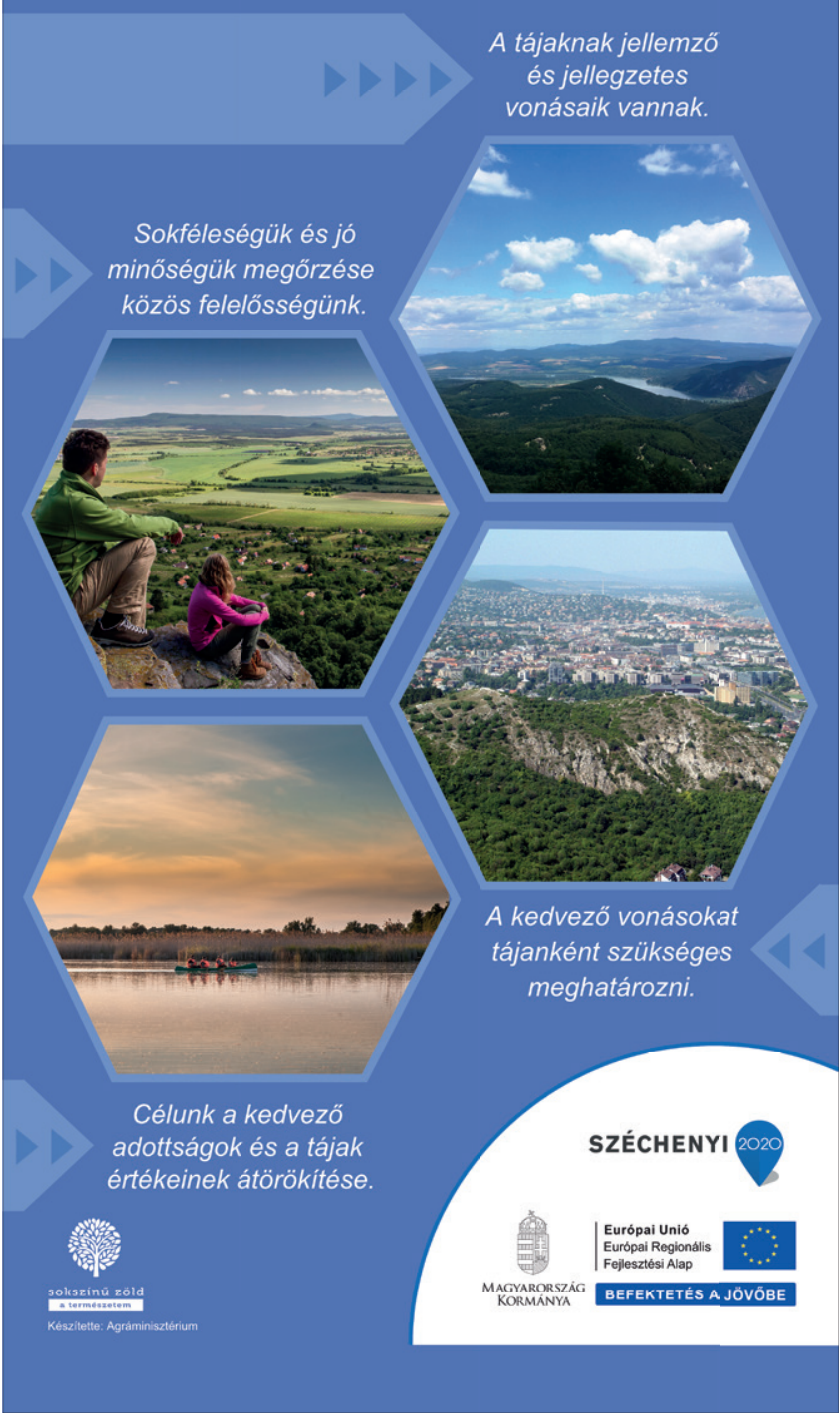

rodalomjegyzék/Literature

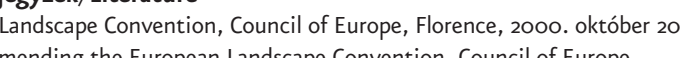
Strasbourg, 2016. augusztus 1. ttps://www.coe.int//n/web/portal

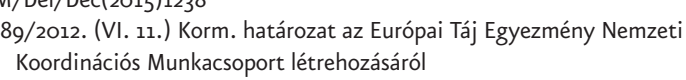

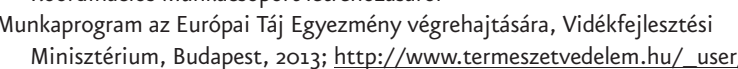

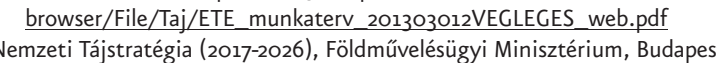

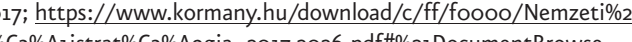

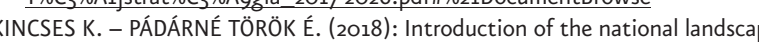
strategy of Hun gary (2017-2026), $4 \mathrm{D} 48$. szam

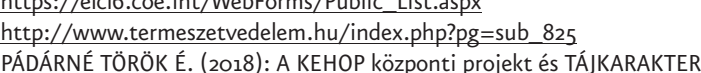

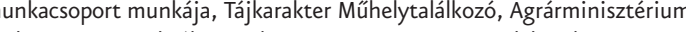

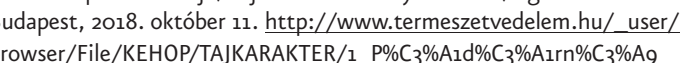

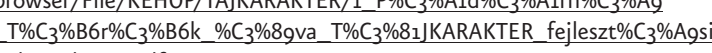
elem-okt_11.pd -TIRÁSZIÁ. - BALÁZSSP. - KOLLÁNYIL. - MÁTÉ K.

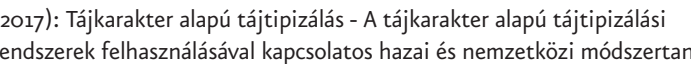

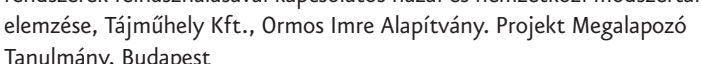
WSZOCSIK V. - CSÓSZI M. FARAGÓNÉ HUSZÁR SZ - CÖNCZ A. - CRÓNÁS - HAMAR J. - KINCSES K. - PÁDÁRNÉ TÖROÓK É. - PODMANICZKY L. - SAIN M. - Ś́RDI A. - TÓTH P. (2017): A hazai tájkarakter alapú tátíipizálís

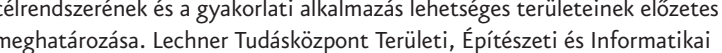
Nonprofit Kft. Budapest; http:///www.termeszetvedelem.hu/_user/browser/ File/KEHOP/TK_tanulmany_final_1.pd

ményeinek beépullése a 2., Budapest, Agrárminiszterium, 2019. aprilis 25. Ittep://Www.termeszetvededem.hu/ user/browser/Filie//KEHOPTAAKAAARTTER -fin.pdf

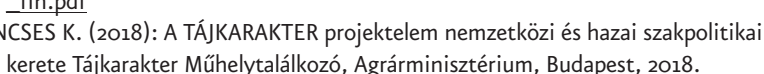
kerete Tajkarakter Múhelytalálikozó, Agrárminiszztérium, Budapest, 2018.
október 11.; http://www.termeszetvedelem.hu/_user/browser/File/KEHOP/

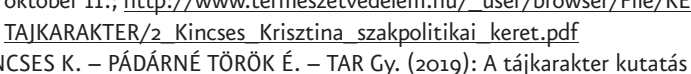

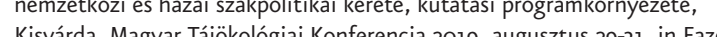

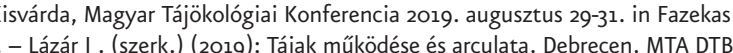
PP. 369-373; ; https://geo.unideb.hu/sites/default/files/file_uploads/

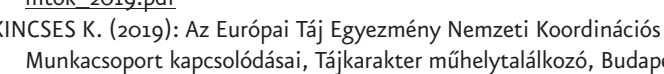

Agrarminisistérium, 2019. februar 7; hthtp://termeszetvedelem.hu/_user/

browser/File/KEHOP/TAKARARTER/O215-cikk/OL_KKincses_Krisztina.pdf 